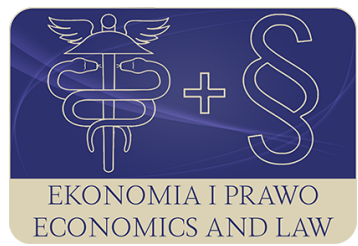

EKONOMIA I PRAWO. ECONOMICS AND LAW

Volume 16, Issue 2, June 2017

p-ISSN 1898-2255, e-ISSN 2392-1625

www.economicsandlaw.pl

ORIGINAL ARTICLE

received 13.06.2017; revised 25.06.2017; accepted 30.06.2017

Citation: Murawska, A. (2017). Influence of population's education level on the employment and unemployment rates in the European Union countries. Ekonomia i Prawo. Ecomomics and Law, 16(2): 171-184. doi:10.12775/EiP.2017.012.

\title{
Influence of population's education level on the employment and unemployment rates in the European Union countries
}

\author{
ANNA MURAWSKA \\ University of Science and Technology in Bydgoszcz, Faculty of Management, Department \\ of Economics and Business Law, ul. Fordońska 430, 85-790 Bydgoszcz, Poland \\ $\checkmark$ anna.murawska@utp.edu.pl
}

\begin{abstract}
Motivation: Population's education level plays an important role, translating into proper performance of work duties and decent salary and, as a result, it is one of the fundamental factors influencing the economic growth and the standard and quality of life.

Aim: The main goal of the article is to specify relationships between the education level of population in individual EU member countries and their labour market situation, especially the employment and unemployment rates. The analyses carried out also aimed to indicate the differences between the countries and gradual changes in the relevant indices in the years 2006-2015. The relationships between the indices analysed and the existing differences and distances between the countries were presented for three groups: The 28 member countries (EU-28), the old 15 (EU-15), and the new 13 European countries that joined the EU in 2004 (EU-13). The assessment of the said issues was based on indices reflecting the education level as well as the employment and unemployment rates of the population. The empirical data were derived from the European Statistical Office. Coefficients of variation, dynamics, and correlation were calculated. In order to describe the statistical data, descriptive and comparative methods were used.

Results: In comparison with the new EU-13 countries, the old EU member countries are home to significantly more uneducated people or people with the lowest level of education, while there is a significantly higher percentage of people with higher education.

When it comes to the level of primary, secondary, and higher education - the distance between the old and the new EU countries is slightly decreasing, while in terms of the percentage of young people who do not work or study and the rate of participation of adults in education, the distance is deepening to the disadvantage of the new member
\end{abstract}


countries. The differences in education level are reflected in the employment and unemployment rates of population.

Keywords: education; employment; unemployment; level; influence; diversification; countries;

European Union

JEL: I24; I25; J21; J64

\section{Introduction}

Productivity of each economy mainly depends on the quantity and quality of its natural resources, tangible assets, the level of production technologies, and the level of job qualifications - meaning the theoretical knowledge and production experience of employees (Nasitowski, 2007, p. 377). At the current stage of development of enterprises, the role of material elements is declining, while the role of human resources is rising (Cybulski, 1999, p. 139). The value of human resources based on education level determines and boosts the growth of enterprises, economies, and people themselves in terms of higher income, stable employment, and, consequently, the sense of living security.

Investments in a person's qualifications are the cheapest way to raise the economic competitiveness and thus boost the pace of economic growth (Auleytner, 2006, p. 75). As early as in 1996, the $19^{\text {th }}$ century report for the UNESCO International Commission on Education presided by Jacques Delors entitled Learning: the Treasure Within emphasised that education should reach far beyond the then-current practices. Education is to complement and update knowledge, retrain, and facilitate professional development of adults. The report stated that education of the society rests on four pillars: 1. Learning to know; 2. Learning to do; 3. Learning to live together; 4. Learning to be (Delors, 1996, p. 37). According to World Bank, considering the conditions shaped by a knowledge-based economy, the educational system is to serve four fundamental functions. First of all, wide primary education is supposed to provide people with skills that are necessary to live in the society; secondly, education should stimulate interests and encourage young people to devote themselves to science and technology; thirdly, education should create diverse labour and develop skills with different levels of difficulty; and finally, education should enable research and advanced training aimed at creating specialised experts to develop science and technology in the future (cf. Radzimińska, 2002).

It is emphasised that education is the basic human right allowing raison d'être and as a public good it should be a common social venture, a process formulated and implemented under a social policy. (cf. Zahorska, 2007, p. 93; Tang, 2015, p. 28). Human resources that enable economic growth are employees with high professional qualifications based on solid education, knowledgeable about IT, speaking foreign languages, mobile, and having motivation for creative and effective actions for the sake of the modern economy (EPIiR, 2016). People equipped with decent theoretical and practical education and financial resources demonstrate higher spatial activity. Therefore, poor and underdeveloped re- 
gions are characterised by a shortage of people with knowledge and investment capabilities. On such areas, one may find underdeveloped human capital that is strongly bound to and dependent on their place of residence. It is emphasised that educational systems should be more closely coordinated with the sphere of real life, while education should incorporate practical skills, especially the requirements of the labour market (Przygodzki, 2012, pp. 117-118).

The existence of significant population groups with insufficient education level may threaten social and economic order and the balance between demand and supply in the labour market. Uneducated people or people with low education level constitute a social issue for the state, the local community and the labour market. A high number of citizens without education that is consistent with the aspirations and development level of a country hampers dynamic growth of the country and limits the possibility of a decent standard of living for those citizens.

\section{Methods}

The main goal of the research is to specify relationships between the education level of population ${ }^{1}$ in individual EU member countries and their labour market situation, especially the employment and unemployment rates. The analyses carried out also aimed to indicate the differences between the countries and gradual changes in the relevant indices in the years 2006-2015. The relationships between the indices analysed and the existing differences and distances between the countries were presented for three groups: 28 member countries (EU-28), the old 15 (EU-15) (Austria, Belgium, Denmark, Finland, France, Greece, Spain, the Netherlands, Ireland, Luxembourg, Germany, Portugal, Sweden, Great Britain, and Italy), and the new 13 European countries that joined the EU in 2004 (EU-13) (Bulgaria, Croatia, Cyprus, Czech Republic, Estonia, Lithuania, Latvia, Malta, Poland, Romania, Slovakia, Slovenia, and Hungary).

Such indices as the following were used to assess the subject matter of the research: percentage of population according to education level attained in the 1564 age group $\left(X_{1}, X_{2}, X_{3}\right)$, percentage of young people aged 15-24 who do not work or study $\left(X_{4}\right)$, rate of participation of adults aged 25-64 in education $\left(X_{5}\right)$ (independent variables), and such variables as total employment and unemployment rates $\left(Y_{1}, Y_{5}\right)$, and employment and unemployment rates depending on education level attained $\left(Y_{2}, Y_{3}, Y_{4}, Y_{6}, Y_{7}, Y_{8}\right)$ (dependent variables) (table l). In order to guarantee international comparability of statistical data in the area of education, UNESCO introduced changes to the current version of the International Standard Classification of Education (ISCED) - ISCED 1997 - so that it is in line with the development goals of education and training policies and structures. The new classification was passed by the UNESCO member

${ }^{1}$ Education means knowledge, skills, and abilities allowing an individual to explore the world that surrounds them and operate effectively in it, as well as perform a specific job; the result of teaching and self-teaching (Słownik Języka Polskiego PWN, 2016). 
countries at the $36^{\text {th }}$ UNESCO General Conference in November 2011. In accordance with Implementing Regulation (EU) No. 81/2013 (2013), education attained is classified as follows: levels 0-2 ISCED 2011 - middle-school education at most, levels 3-4 ISCED 2011 - post-middle-school and post-secondary education (excluding higher education), levels 5-8 ISCED 2011 - higher education (UNESCO, 2012).

The empirical data were derived from the information collected by the Eurostat (2016). The analysis covered the $28 \mathrm{EU}$ member countries. The research period spanned from 2006 to 2015. Coefficients of variation (coefficient of variation $V_{s}$ and range $R$ ), dynamics $I_{s}$ and correlation $r_{x y}$ were calculated among others. In order to describe the statistical data, descriptive and comparative methods were used.

\section{Changes in the education level and the labour market situation in the EU countries}

In the EU member countries, $26.9 \%$ of population aged $15-64$ has middle-school education at most, $46.4 \%$ - post-middle-school education although not higher than post-secondary education, and $26.7 \%$ - higher education, whereas the countries are significantly diversified in that respect, which is evidenced by the calculated coefficient of variation $V_{s}$ (table 2).

More people with middle-school education at best or uneducated people live in the 'old' member countries (29.2\% on average), with the highest percentage in Portugal (54.4\%), Spain (43.5\%), and Italy (41.9\%) and the lowest in Finland (19.2\%), Austria (19.6\%), and Germany (19.8\%). However, in the new member countries, people with the lowest education or uneducated people account for $21.2 \%$ on average, with the highest percentage in Malta (52.4\%), Romania (29.4\%), and Cyprus (25.6\%), and the lowest in Czech Republic (12.4\%), Lithuania (13.8\%), and Slovakia (14.6\%). Post-middle-school education, but not higher than post-secondary school education, is more often held by residents of the new EU member countries. It turns out that, in the old EU member countries, an average of $40.9 \%$ of population aged $15-64$ is educated at the $3-4$ ISCED level, while in the new member countries the value is $54.3 \%$. Most people from EU-15 with such an education level lives in: Germany (56.4\%), Austria (52.3\%), while from EU-13 in: Czech Republic (67.8\%), Slovakia (66.5\%), and Poland and Croatia (60\%). However, the lowest number of people from EU-15 with secondary education lives in: Spain (24.4\%) and Portugal (24.9\%), while from EU-13 in: Malta (29.5\%) and Cyprus (38.1\%). Higher education is held by an average of $30 \%$ of population living in the old EU countries and $24.5 \%$ in the new. In EU-15, the highest number of people with higher education lives in Great Britain (37.6\%) and Ireland (37.4\%), while the lowest in Italy (15.5\%) and Portugal (20.7\%). On the other hand, in EU-13, most people with higher education live in such countries as Cyprus (36.3\%) and Estonia and Lithuania (33\%), while least in: Romania (15.0\%) and Malta (18.1\%). 
In the recent years, we have been facing a significant issue for economic growth, labour market stability, and social policy goals, which is young people who do not study or work. It turns out that in 2015, the percentage of young people in EU-28 who do not study or work (aged 15-24) amounted to 11.7\%, while in the old member countries it was $10.9 \%$ and in the new $-12.7 \%$. The highest number of young people do not study or work in such countries as: Italy (21.4\%), Greece (17.2\%) and Bulgaria (19.3\%), Croatia (18.5\%), and Cyprus (18.1\%), while the lowest number in such countries as: the Netherlands (4.7\%), Denmark, Luxembourg, Germany, Sweden (ca. 6.0\%), and Czech Republic (7.5\%).

A significant advantage of each developing economy is mobilisation of people at working age and who have already completed formal education (institutionalised) to participate in professional education and training in order to raise their qualifications and skills in the course of their personal and professional life. In EU-28, the total rate of participation in professional education and training in 2015 was $10.7 \%$, while in the EU-15 countries - 14.9\% and in the EU-13 countries - 6.1\%. This index is the highest in Denmark (31.3\%) and in Sweden (29.4\%), while the lowest in Romania (1.3\%) and in Bulgaria (2.0\%) (table 2).

The second group of indices subject to analysis characterises the labour market, especially the employment and unemployment rates. General population's employment rate in the 20-64 age group for the EU-28 countries in 2015 amounted to $70.1 \%$, while in the old member countries is slightly higher $(70.6 \%)$ than in the new (69.2\%). Differences between the countries in terms of this index are low and insignificant $\left(V_{s}<10 \%\right)$; nevertheless, it must be emphasised that the highest employment rate is recorded for Sweden (80.5\%) and Germany (78.0\%), while the lowest for Italy and Croatia (60.5). Total unemployment rate in the 15-74 age group in 2015 in the EU-28 countries equalled 9.4\%, in the EU-15 countries - 10.1\%, and in the EU-13 countries - 9.1\%. Significant differences can be observed between the 'old' member countries in terms of their unemployment rate, because in such countries as Greece or Spain even every fifth person is unemployed, while in such countries as Germany, Great Britain or Austria, unemployment rate oscillates around 5\%. In the new member countries, the unemployment rate is less varied - the highest unemployment is recorded for Cyprus (15.0\%) and for Croatia (16.35), while the lowest for Czech Republic (5.1\%) and Malta (5.4\%).

Based on the analysis of changes in the structure of the education level of population as well as the employment and unemployment rates, several significant trends can be observed (table 3). The visible dynamics of changes taking place in the education level of the population living in the European countries reflects the positive trends towards the higher quality of human capital in terms of knowledge, skills, and professional competencies. The calculated individual fixed base indices Is show that in the years 2006-2015 in the EU-28 countries in general as well as in the groups of the old and the new member countries, the percentage of people with the lowest education decreased significantly, 
while the percentage of people with higher education increased significantly. The dynamics of changes is significantly higher in the new member countries than in the old, which means positive evolution towards a higher quality of social capital of the countries which joined EU in 2004. The 'old' member countries are significantly different from the new countries in terms of the lower percentage of people with secondary education, but in the recent years no transparent changes in the existing disproportions have been observed in that respect.

As previously touched upon, the EU countries have been facing the dilemma relating to the higher number of young people who do not work nor study. While the percentage of those people is higher in the new member countries (12.7\%), the value of the Is index in the years 2006-2015 estimated for EU-15 at $115.6 \%$ demonstrates a significant rise in the scale and ramifications of this phenomenon for the labour market in the future, which concerns the old member countries as well.

As mentioned previously, in the old member countries in 2015, every seventh person aged 25-64 participated in professional education or training, while in the new countries, it was only every sixteenth person. Furthermore, in the EU-15 countries, this index rose in the years $2006-2015$ by $18.8 \%$, while in EU-13 only by $10.0 \%$. The too low dynamics of changes in the new member countries in terms of continuous education following completion of formal education may contribute in the future to reducing the quality of human capital and to problems with meeting the labour market needs for workforce with specific qualifications.

Labour market situation is well reflected by the changes in the total employment and unemployment rates, and the employment and unemployment rates depending on the education level of population over a longer period. Data from table 3 show that in the years 2006-2015, despite the dynamics of changes regarding the employment rate being insignificant, unfavourable changes in the unemployment scale took place.

The lowest employment rate is recorded for the group of people with the lowest education (level 0-2 acc. ISCED) and rises as the education level increases. While the employment rate in the group of people with the education level 0-2 acc. ISCED amounted to $50.7 \%$, for the ISCED level 3-4 it was $69.6 \%$, and for the ISCED level $5-8-82.6 \%$. When we compare the two analysed groups of the EU countries, the employment rate in the old member countries is higher at the ISCED education levels $0-2$ and 3-4, while in the new countries it is higher at the ISCED level 5-8.

As a result of the economic crisis that started in the United States in 2007, labour market problems began to occur in the EU countries, which led to higher unemployment. Based on the analysed indices of dynamics $I_{s}$, we can observe that the old EU countries had to face significantly higher rise in unemployment $\left(I_{s}=149.6 \%\right)$ than those which joined EU in $2004\left(I_{s}=111.6 \%\right)$. People with the lowest education is the group with the highest unemployment rate, with a higher unemployment rate among people with education at the ISCED level 
0-2 occurring in the new member countries (19.4\%). However, among people with the ISCED 3-4 and 5-8 education levels, the unemployment rate is slightly, but still higher in the old member countries.

The results of analyses contained in table 4 demonstrate changes in the distance between the EU-15 and EU-13 countries in the years 2006-2015 both in terms of population's education level and the employment and unemployment rates. Based on those calculations, we can observe that the distance between the 'old' and the 'new' EU countries slightly decreased in terms of the percentage of people aged 15 to 64 with middle-school education, completed primary education or without education (levels $0-2$ acc. ISCED) and considerably decreased in terms of the percentage of people with post-middle-school education, basic vocational education, secondary vocational education, secondary education, and post-secondary education (levels 3-4 acc. ISCED). The distance between the countries increased however in the recent years (up to 2014) in terms of the rate of participation in professional education and training. Not only do the new member countries demonstrate this rate at a very low level, but in the last decade the differences started to deepen even more.

The distance between the EU-15 and the EU13 countries in terms of total employment rates is decreasing, with the difference calculated in the population with the ISCED education levels of 1-2 and 3-4 and in 2015 (range $R$ ) being the lowest. When it comes to the distance between the old and the new countries in terms of the unemployment rate, the trends are slightly different. Only for the unemployment rate among people with the lowest education, the difference between the two groups of countries was the lowest in 2015. In the case of the remaining indices $Y_{5}, Y_{7}$, and $Y_{8}$, while the distances dropped to the lowest levels in the years 2011-2013, the differences between EU-15 and EU-13 started to deepen again in the years to follow (table 4).

\section{Relationships between population's education and the employment and unemployment rates in the European Union}

The calculated relationships between the indices characterising education level and the indices describing labour market situation confirm the significant impact of the education level of the society on the employment and unemployment rates. Analysing the data presented in table 5, we may observe that there is a significant correlation between the indices describing education level and those describing the employment and unemployment, with such a correlation being more frequently significant in the old member countries than in the new.

When we look at the member countries in general (EU-28), we can come to the conclusion that with the rise of the percentage of people with the lowest education, the total employment rate drops $\left(r_{x y}=-0.40\right)$, but the employment rate among the people with the lowest education rises $\left(r_{x y}=0.41\right)$. The 
employment rate is significantly influenced by the percentage of people with higher education $\left(r_{x y}=0.42\right)$ and the rate of participation in professional education and training, which is evidenced by a positive coefficient of correlation $\left(r_{x y}=0.61, r_{x y}=0.59, r_{x y}=0.57\right)$. However, negative influence on both the employment and unemployment rate is exerted by the percentage of young people who do not study nor work.

The strength and range of the negative influence of the number of young people who do not work and do not study at the same time on the labour market situation is disturbing, especially in the group of the old member countries, where, as opposed to the new member countries, the calculated relationships were significant for all the variables analysed. In the old member countries, we can more frequently observe significant influence of the rate of participation in professional education and training after completing formal education on the employment and unemployment rates, which is evidenced by significant coefficients of correlation.

In the new member countries, the influence of the education level on the labour market situation is not as transparent and obvious anymore, which is confirmed by the lack of significance of the calculated coefficients of correlation. Nevertheless, we can explicitly state that the higher is the percentage of people with the lowest education (levels $0-2$ acc. ISCED) in an EU-13 country, the higher is the unemployment rate in the same country $\left(r_{x y}=-0.68\right)$. In the EU-13 countries, the employment rate, especially the employment rate among people with the education level 3-4 acc. ISCED, who are the most numerous in those countries, is negatively influenced by the percentage of people who do not study or work $\left(r_{x y}=-0.74, r_{x y}=-0.58\right)$, while positively by the rate of participation in professional education and training $\left(r_{x y}=0.63\right)$.

\section{Conclusion}

The EU countries vary significantly in terms of education level. In comparison with the new EU-13 countries, the old member countries are home to significantly more uneducated people or people with the lowest level of education, while there is a significantly higher percentage of people with higher education. It must be noted that there is a dynamic drop of the percentage of people at the lowest level of education and a dynamic rise in the number of people with higher education, with the dynamics of changes significantly higher in the countries that joined the EU in 2004. When it comes to the level of primary, secondary, and higher education - the distance between the old and the new EU countries is slightly decreasing, while in terms of the percentage of young people who do not work or study and the rate of participation of adults in education, the distance is deepening to the disadvantage of the new member countries.

The differences and trends in education level are reflected in the employment and unemployment rates of population. The percentage of people with the lowest education, the percentage of young people who do not work nor 
study, and the rate of participation in professional education and training after completing formal education play a significant role in stimulating or inhibiting the employment and unemployment rates in the European countries, with the importance of those variables being higher in the old member countries (EU-15) than in the new (EU-13).

We may then conclude that population's education level plays an important role, translating into proper performance of work duties and decent salary, is one of the basic factors influencing the labour market and the employment and unemployment rates, and, as a result, it translates into economic growth and a higher standard and quality of life. Education of the society is fundamental for the development of enterprises, economies, and people themselves in terms of providing them with the higher sense of possible job security and, consequently, the sense of living security.

\section{References}

Auleytner, J.M. (2006). Edukacja i kreowanie kapitału ludzkiego. In A. Kurzynowski (Ed.), Polityka spoteczna. Warszawa: SGH IGS.

Commission Implementing Regulation (EU) No 81/2013 of 29 January 2013 amending Implementing Regulation (EU) No 1051/2011 as regards the micro-data files for the transmission of data Text with EEA relevance (OJ L 28, 30.1.2013).

Cybulski, L. (1999). Edukacja a konkurencyjność regionów. In M. Klamut (Ed.), Konkurencyjność regionów. Wrocław: Wydawnictwo Akademii Ekonomicznej im. Oskara Langego we Wrocławiu.

Delors, J. (ed.) (1996). Learning: the treasure within. Report to UNESCO of the International Commission on Education for the twenty-first century. Retrieved 08.11.2016 from http://unesdoc.unesco.org.

EPIiR. (2016). Gospodarka oparta na wiedzy. Retrieved 08.11.2016 from http:// europejskiportal.eu.

Eurostat. (2016). Retrieved 23.12.2016 from http://ec.europa.eu/eurostat.

Nasiłowski, M. (2007). System rynkowy. Podstawy mikro- i makroekonomii. Warszawa: Key Text.

Przygodzki, Z. (2012). Konkurencyjność regionów. In J. Chądzyński, A. Nowakowska, \& Z. Przygodzki (Eds.), Region i jego rozwój w warunkach globalizacji. Warszawa: CeDeWu.

Radzimińska, T. (2002). W stronę gospodarki wiedzy. Nowe Życie Gospodarcze, 6. Słownik Języka Polskiego PWN. (2016). Retrieved 15.11.2016 from http://sjp. pwn.pl.

Tang, Q. (Ed.) (2015). Education 2030. Incheon declaration and framework for action for the implementation of sustainable development. Goal 4. Retrieved 08.11.2016 from http://unesdoc.unesco.org.

UNESCO. (2012). International standard classification of education ISCED 2011. Retrieved 11.11.2016 from http://www.uis.unesco.org. 
Zahorska, M. (2007). Zmiany w polskiej edukacji i ich społeczne konsekwencje. In M. Marody (Ed.), Wymiary życia spotecznego. Polska na przetomie XX i XXI wieku. Warszawa: SCHOLAR.

\section{Acknowledgements}

Author contributions: author has given an approval to the final version of the article.

Funding: The research was undertaken as part of statutory research and was fully financed by the resources at the disposal of the Department of Economics and Business Law, Faculty of Management, University of Science and Technology in Bydgoszcz (No. BS 4/2016).

Note: the results of this study were presented at 9th International Conference on Applied Economics Contemporary issues in Economy (Toruń, June 22-23, Toruń, Poland). 


\section{Appendix}

Table 1 .

Indices considered during the analysis of the relationship between the education level and the labour market situation in the EU-28, EU-15, and EU-13 countries

\begin{tabular}{|c|c|}
\hline \multicolumn{2}{|r|}{ Education Level Indices } \\
\hline$X_{1}$ & $\begin{array}{l}\text { Percentage of people aged } 15-64 \text { with middle-school education, completed primary education, or } \\
\text { uneducated (levels } 0-2 \text { according to ISCED) }\end{array}$ \\
\hline$X_{2}$ & $\begin{array}{l}\text { Percentage of people aged 15-64 with post-middle-school education, basic vocational education, sec- } \\
\text { ondary vocational education, secondary, and post-secondary education (levels 3-4 according to ISCED) }\end{array}$ \\
\hline$X_{3}$ & Percentage of people aged 15-64 with higher education (levels 5-8 according to ISCED) \\
\hline$X_{4}$ & $\begin{array}{l}\text { Percentage of young people who do not work or study among general population in the same age group, } \\
\text { that is } 15-24 \text { years old. }\end{array}$ \\
\hline$X_{5}$ & Total rate of participation in professional education and training (last 4 weeks) in the 25-64 age group \\
\hline \multicolumn{2}{|r|}{ Labour Market Indices } \\
\hline$Y_{1}$ & General population employment rate in the 20-64 age group \\
\hline$Y_{2}$ & $\begin{array}{l}\text { Employment rate among the population aged 20-64 with middle-school education at best (level 0-2 } \\
\text { according to ISCED) }\end{array}$ \\
\hline$Y_{3}$ & $\begin{array}{l}\text { Employment rate among the population aged 20-64 with post-middle-school and post-secondary } \\
\text { education, excluding higher education (level } 3 \text { and } 4 \text { according to ISCED) }\end{array}$ \\
\hline$Y_{4}$ & $\begin{array}{c}\text { Employment rate among the population aged } 20-64 \text { with higher education (level 5-8 according } \\
\text { to ISCED) }\end{array}$ \\
\hline$Y_{5}$ & Total unemployment rate (\%) among the 15-74 age group \\
\hline$Y_{6}$ & $\begin{array}{l}\text { Unemployment rate (\%) among the } 15-74 \text { age group with middle-school education at best (level 0-2 } \\
\text { according to ISCED) }\end{array}$ \\
\hline$Y_{7}$ & $\begin{array}{l}\text { Total unemployment rate among the 15-74 age group with post-middle-school and post-secondary } \\
\text { education, excluding higher education (level } 3 \text { and } 4 \text { according to ISCED) }\end{array}$ \\
\hline$Y_{8}$ & $\begin{array}{c}\text { Total unemployment rate (\%) among the } 15-74 \text { age group with higher education (level } 5-8 \text { according } \\
\text { to ISCED) }\end{array}$ \\
\hline
\end{tabular}

Source: own preparation based on Eurostat (2016). 
Table 2.

Indices characterising the education level and the labour market situation in EU-28, EU-15, and EU-13 in 2015

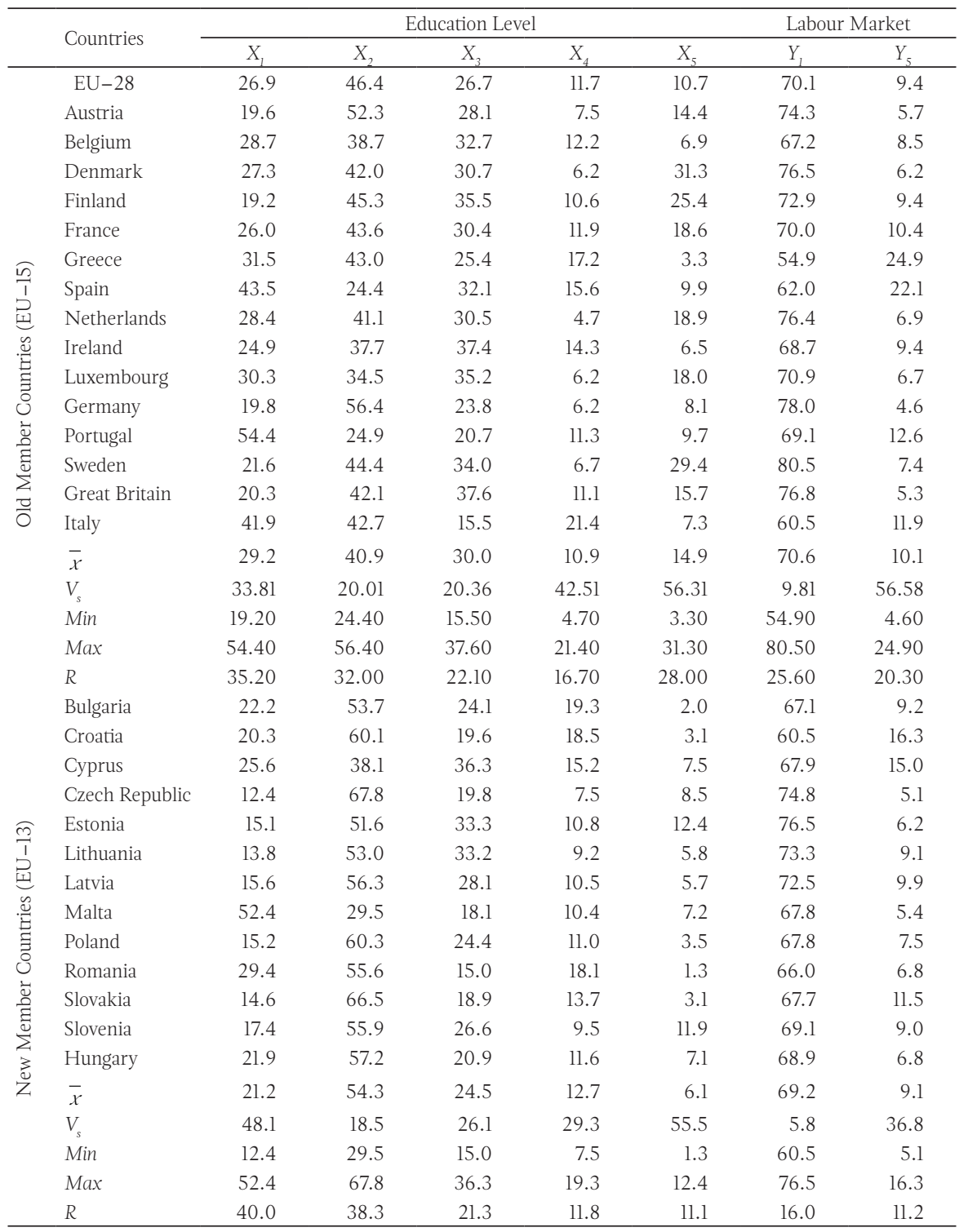

Note:

$\bar{x}$ - arithmetic mean; $V_{s}$ - coefficient of variation in \%; Min - minimum, Max - maximum, $R-$ range. The indices $X_{1}$ to $X_{5}^{s}$ and $Y_{1}$ and $Y_{5}$ are described in table 1 .

Source: own calculations based on Eurostat (2016). 
Table 3.

Population's education level and the labour market situation in the EU-28, EU-15, and EU-13 countries, and the dynamics of changes occurring in the years 2006-2015

\begin{tabular}{|c|c|c|c|c|c|c|c|c|c|c|c|c|}
\hline Indices & ountry groups & 2006 & 2007 & 2008 & 2009 & 2010 & 2011 & 2012 & 2013 & 2014 & 2015 & $I_{s}$ \\
\hline \multirow{3}{*}{$X_{1}$} & EU-28 & 32.5 & 32.0 & 31.3 & 30.2 & 29.4 & 28.6 & 27.5 & 26.6 & 25.9 & 25.5 & 78.3 \\
\hline & EU-15 & 36.4 & 36.3 & 35.6 & 34.3 & 33.6 & 32.7 & 31.7 & 30.6 & 29.5 & 29.2 & 80.0 \\
\hline & EU-13 & 28.0 & 27.1 & 26.3 & 25.5 & 24.6 & 23.8 & 22.7 & 22.0 & 21.8 & 21.2 & 75.7 \\
\hline \multirow{3}{*}{$X_{2}$} & EU-28 & 47.5 & 47.5 & 47.6 & 47.7 & 47.6 & 47.7 & 47.8 & 47.8 & 47.2 & 47.1 & 99.1 \\
\hline & EU-15 & 40.8 & 40.6 & 40.7 & 40.9 & 40.9 & 41.1 & 41.2 & 41.4 & 40.9 & 40.9 & 100.1 \\
\hline & EU-13 & 55.3 & 55.5 & 55.4 & 55.5 & 55.4 & 55.2 & 55.4 & 55.2 & 54.5 & 54.3 & 98.2 \\
\hline \multirow{3}{*}{$X_{3}$} & EU-28 & 20.0 & 20.5 & 21.2 & 22.1 & 22.9 & 23.8 & 24.7 & 25.6 & 26.8 & 27.4 & 137.4 \\
\hline & EU-15 & 22.7 & 23.1 & 23.7 & 24.8 & 25.4 & 26.2 & 27.1 & 28.0 & 29.5 & 30.0 & 131.8 \\
\hline & EU-13 & 16.8 & 17.4 & 18.2 & 19.0 & 20.0 & 20.9 & 21.9 & 22.8 & 23.7 & 24.5 & 146.1 \\
\hline \multirow{3}{*}{$X_{4}$} & EU-28 & 10.7 & 10.1 & 9.9 & 11.8 & 12.1 & 12.3 & 12.8 & 12.8 & 12.3 & 11.7 & 109.8 \\
\hline & EU-15 & 9.4 & 9.3 & 9.7 & 11.1 & 11.1 & 11.4 & 11.9 & 11.7 & 11.3 & 10.9 & 115.6 \\
\hline & EU-13 & 12.1 & 10.9 & 10.2 & 12.5 & 13.3 & 13.4 & 13.7 & 14.0 & 13.3 & 12.7 & 104.7 \\
\hline \multirow{3}{*}{$X_{5}$} & EU-28 & 9.3 & 9.2 & 9.5 & 9.6 & 9.8 & 10.2 & 10.2 & 10.7 & 10.6 & 10.8 & 116.3 \\
\hline & EU-15 & 12.5 & 12.1 & 12.6 & 13.0 & 13.2 & 13.4 & 13.6 & 14.6 & 14.8 & 14.9 & 118.8 \\
\hline & EU-13 & 5.5 & 5.7 & 5.9 & 5.7 & 5.9 & 6.4 & 6.3 & 6.2 & 5.8 & 6.1 & 110.0 \\
\hline \multirow{3}{*}{$Y_{1}$} & EU-28 & 69.7 & 70.6 & 71.0 & 69.1 & 68.1 & 68.1 & 68.0 & 68.0 & 68.9 & 70.0 & 100.4 \\
\hline & EU-15 & 71.6 & 72.3 & 72.5 & 71.1 & 70.4 & 70.1 & 69.6 & 69.4 & 70.0 & 70.6 & 98.5 \\
\hline & EU-13 & 67.4 & 68.7 & 69.3 & 66.8 & 65.5 & 65.7 & 66.1 & 66.4 & 67.8 & 69.2 & 102.7 \\
\hline \multirow{3}{*}{$Y_{2}$} & EU-28 & 53.5 & 54.6 & 54.4 & 51.8 & 50.6 & 50.0 & 49.5 & 49.3 & 50.1 & 50.7 & 94.8 \\
\hline & EU-15 & 59.3 & 60.1 & 59.7 & 57.4 & 56.3 & 55.7 & 54.8 & 54.0 & 53.9 & 54.5 & 91.8 \\
\hline & EU-13 & 46.7 & 48.3 & 48.4 & 45.4 & 44.0 & 43.4 & 43.4 & 43.8 & 45.7 & 46.4 & 99.3 \\
\hline \multirow{3}{*}{$Y_{3}$} & EU-28 & 71.4 & 72.3 & 72.4 & 70.0 & 68.8 & 68.5 & 68.2 & 68.0 & 68.7 & 69.6 & 97.4 \\
\hline & EU-15 & 72.9 & 73.6 & 73.6 & 71.8 & 71.1 & 70.5 & 69.8 & 69.4 & 69.7 & 70.3 & 96.4 \\
\hline & EU-13 & 69.8 & 70.8 & 71.1 & 67.9 & 66.1 & 66.1 & 66.3 & 66.2 & 67.5 & 68.7 & 98.5 \\
\hline \multirow{3}{*}{$Y_{4}$} & EU-28 & 84.1 & 84.6 & 84.6 & 83.3 & 82.2 & 82.0 & 81.7 & 81.3 & 81.8 & 82.6 & 98.2 \\
\hline & EU-15 & 83.9 & 84.3 & 84.4 & 83.4 & 82.7 & 82.3 & 81.8 & 81.4 & 81.5 & 81.9 & 97.7 \\
\hline & EU-13 & 84.3 & 84.9 & 85.0 & 83.3 & 81.7 & 81.8 & 81.4 & 81.3 & 82.0 & 83.3 & 98.9 \\
\hline \multirow{3}{*}{$Y_{5}$} & EU-28 & 7.4 & 6.5 & 6.3 & 8.9 & 10.1 & 10.1 & 10.8 & 11.1 & 10.5 & 9.6 & 130.2 \\
\hline & EU-15 & 6.8 & 6.3 & 6.3 & 8.4 & 9.1 & 9.5 & 10.7 & 11.2 & 10.7 & 10.1 & 149.6 \\
\hline & EU-13 & 8.1 & 6.7 & 6.3 & 9.4 & 11.2 & 10.7 & 11.0 & 11.1 & 10.2 & 9.1 & 111.6 \\
\hline \multirow{3}{*}{$Y_{6}$} & EU-28 & 13.0 & 11.7 & 11.7 & 15.7 & 17.6 & 18.0 & 19.1 & 19.5 & 18.6 & 17.5 & 135.0 \\
\hline & EU-15 & 10.1 & 9.5 & 9.9 & 12.7 & 13.9 & 14.6 & 16.2 & 17.1 & 16.6 & 15.8 & 157.0 \\
\hline & EU-13 & 16.3 & 14.2 & 13.8 & 19.2 & 21.9 & 21.9 & 22.5 & 22.3 & 21.0 & 19.4 & 119.2 \\
\hline \multirow{3}{*}{$Y_{7}$} & EU-28 & 7.2 & 6.2 & 6.1 & 9.0 & 10.4 & 10.4 & 11.2 & 11.6 & 10.9 & 10.0 & 139.2 \\
\hline & EU-15 & 6.6 & 6.0 & 6.2 & 8.3 & 9.1 & 9.6 & 11.0 & 11.6 & 11.2 & 10.4 & 158.3 \\
\hline & EU-13 & 7.9 & 6.4 & 6.0 & 9.8 & 11.8 & 11.2 & 11.4 & 11.5 & 10.6 & 9.5 & 120.7 \\
\hline \multirow{3}{*}{$Y_{8}$} & EU-28 & 4.0 & 3.7 & 3.4 & 4.8 & 5.6 & 5.7 & 6.3 & 6.7 & 6.3 & 5.8 & 144.4 \\
\hline & EU-15 & 4.3 & 4.0 & 3.8 & 5.0 & 5.4 & 5.8 & 6.5 & 7.0 & 6.8 & 6.6 & 152.5 \\
\hline & EU-13 & 3.7 & 3.2 & 3.0 & 4.5 & 5.8 & 5.6 & 6.0 & 6.3 & 5.7 & 5.0 & 133.6 \\
\hline
\end{tabular}

Note:

$I_{s}$ - coefficient of dynamics for $2015(2006=100)$. The indices $X_{1}-X_{5}$ and $Y_{1}-Y_{8}$ are described in tablel.

Source: own calculations based on Eurostat (2016). 
Table 4.

Changes in the distance between the EU-15 and EU-13 countries in terms of population's education level and labour market situation in the years 2006-2015

\begin{tabular}{crrrrrrrrrr}
\hline Indices & 2006 & 2007 & 2008 & 2009 & 2010 & 2011 & 2012 & 2013 & 2014 & 2015 \\
\hline$X_{1}$ & 8.4 & 9.2 & 9.2 & 8.8 & 9.0 & 8.8 & 9.0 & 8.6 & 7.7 & 7.9 \\
$X_{2}$ & -14.4 & -14.9 & -14.7 & -14.7 & -14.6 & -14.2 & -14.2 & -13.8 & -13.6 & -13.4 \\
$X_{3}$ & 6.0 & 5.7 & 5.5 & 5.8 & 5.5 & 5.3 & 5.2 & 5.2 & 5.8 & 5.5 \\
$X_{4}$ & -2.7 & -1.6 & -0.5 & -1.4 & -2.2 & -2.0 & -1.8 & -2.3 & -2.0 & -1.8 \\
$X_{5}$ & 7.0 & 6.4 & 6.7 & 7.3 & 7.3 & 7.0 & 7.3 & 8.4 & 9.0 & 8.8 \\
$Y_{1}$ & 4.2 & 3.6 & 3.2 & 4.2 & 4.9 & 4.4 & 3.5 & 3.0 & 2.2 & 1.4 \\
$Y_{2}$ & 12.6 & 11.9 & 11.2 & 11.9 & 12.3 & 12.3 & 11.4 & 10.2 & 8.2 & 8.1 \\
$Y_{3}$ & 3.1 & 2.8 & 2.5 & 3.9 & 4.9 & 4.5 & 3.5 & 3.2 & 2.2 & 1.5 \\
$Y_{4}$ & -0.4 & -0.6 & -0.6 & 0.1 & 1.0 & 0.5 & 0.4 & 0.1 & -0.5 & -1.4 \\
$Y_{5}$ & -1.3 & -0.4 & 0.0 & -1.1 & -2.2 & -1.2 & -0.3 & 0.2 & 0.6 & 1.1 \\
$Y_{6}$ & -6.2 & -4.7 & -3.9 & -6.4 & -8.0 & -7.3 & -6.4 & -5.2 & -4.3 & -3.6 \\
$Y_{7}$ & -1.3 & -0.4 & 0.1 & -1.5 & -2.7 & -1.6 & -0.4 & 0.0 & 0.5 & 0.9 \\
$Y_{8}$ & 0.6 & 0.8 & 0.8 & 0.5 & -0.4 & 0.3 & 0.5 & 0.8 & 1.1 & 1.6 \\
\hline
\end{tabular}

Note:

distance (range $R$ ) — difference between the mean values of variables for the EU-15 countries and for the EU-13 countries. The indices $X_{1}-X_{5}$ and $Y_{1}-Y_{8}$ are described in table 1 .

Source: own calculations based on Eurostat (2016).

Table 5.

Relationships $\left(r_{x y}\right)$ between the indices characterising population's education level and the labour market situation in the EU-28, EU-15, and EU-13 countries

\begin{tabular}{|c|c|c|c|c|c|c|c|c|c|}
\hline & Indices & $Y_{1}$ & $Y_{2}$ & $Y_{3}$ & $Y_{4}$ & $Y_{5}$ & $Y_{6}$ & $Y_{7}$ & $Y_{8}$ \\
\hline \multirow{5}{*}{$\begin{array}{l}\stackrel{\infty}{\sim} \\
\stackrel{1}{p} \\
\stackrel{D}{D}\end{array}$} & $X_{1}$ & $-0.40^{*}$ & $0.41^{*}$ & -0.13 & -0.22 & 0.31 & -0.23 & 0.23 & 0.32 \\
\hline & $X_{2}$ & 0.13 & $-0.60^{*}$ & 0.05 & 0.11 & -0.28 & 0.26 & -0.24 & -0.34 \\
\hline & $X_{3}$ & $0.42^{*}$ & 0.35 & 0.12 & 0.16 & -0.02 & -0.07 & 0.03 & 0.05 \\
\hline & $X_{4}$ & $-0.81^{*}$ & $-0.44^{*}$ & $-0.71^{*}$ & $-0.62^{*}$ & $0.59^{*}$ & 0.37 & $0.57^{*}$ & $0.49^{*}$ \\
\hline & $X_{5}$ & $0.61^{*}$ & $0.59^{*}$ & $0.57^{*}$ & 0.33 & -0.29 & -0.36 & -0.33 & -0.18 \\
\hline \multirow{5}{*}{$\begin{array}{l}\text { 늠 } \\
1 \\
? \\
?\end{array}$} & $X_{1}$ & $-0.57^{*}$ & -0.45 & 0.05 & -0.50 & $0.55^{*}$ & 0.32 & $0.52^{*}$ & 0.51 \\
\hline & $X_{2}$ & 0.40 & 0.39 & -0.05 & 0.33 & -0.47 & -0.38 & -0.46 & -0.40 \\
\hline & $X_{3}$ & 0.39 & 0.20 & -0.02 & 0.36 & -0.25 & -0.02 & -0.23 & -0.28 \\
\hline & $X_{4}$ & $-0.86^{*}$ & $-0.77^{*}$ & $-0.67^{*}$ & $-0.83^{*}$ & $0.68^{*}$ & $0.59^{*}$ & $0.69^{*}$ & $0.61^{*}$ \\
\hline & $X_{5}$ & $0.68^{*}$ & $0.65^{*}$ & 0.49 & $0.61^{*}$ & -0.47 & -0.31 & $-0.52^{*}$ & -0.43 \\
\hline \multirow{5}{*}{$\frac{m}{1}$} & $X_{1}$ & -0.36 & 0.46 & 0.29 & 0.31 & -0.17 & $-0.56^{*}$ & -0.28 & -0.13 \\
\hline & $X_{2}$ & 0.06 & $-0.68^{*}$ & -0.22 & -0.37 & 0.01 & 0.53 & 0.04 & -0.12 \\
\hline & $X_{3}$ & 0.49 & 0.34 & -0.12 & 0.08 & 0.26 & 0.07 & 0.38 & 0.38 \\
\hline & $X_{4}$ & $-0.74^{*}$ & -0.12 & $-0.58^{*}$ & -0.39 & 0.53 & 0.05 & 0.43 & 0.46 \\
\hline & $X_{5}$ & $0.63^{*}$ & 0.47 & 0.46 & 0.14 & -0.28 & -0.31 & -0.21 & -0.08 \\
\hline
\end{tabular}

Note:

$r_{x y}$ - coefficient of correlation, ${ }^{*}$ - correlation is significant at the level of 0.05 . The indices $X_{1}-X_{5}$ and $Y_{1}-Y_{8}$ are described in table 1.

Source: own calculations based on Eurostat (2016). 